\title{
Multiyear Fast Ice along the Taymyr Peninsula, Siberia
}

\author{
ERK REIMNITZ, ${ }^{1}$ HAJO EICKEN,${ }^{2}$ and THOMAS MARTIN ${ }^{2}$
}

(Received 20 October 1994; accepted in revised form 10 July 1995)

\begin{abstract}
A $20 \mathrm{~km}$ wide zone of fast ice, reaching offshore to the $20 \mathrm{~m}$ isobath and sealing off coastal embayments along the Taymyr Peninsula, survived until at least 23 November 1993, becoming multiyear land-fast sea ice (MLSI). Barrier islands show characteristic recurved spits indicating dominant southeastward direction of longshore transport in intermittent years. At the time of observation, the fast ice was undisturbed, only heaving vertically with tides, protecting the coastal zone from wave reworking. The 1 to $2 \mathrm{~m}$ thick ice cover affects light and oxygen, creating profound effects on marine life in the zone. A herd of walrus, in other summers reported to haul out on local beaches, was displaced by the fast ice. We saw no evidence for sediment loading of the ice by rivers or for eolian deposition on ice.

MLSI is considered an incipient ice shelf, which could grow in thickness and strength in successive winters. Salinity and $\delta^{18} \mathrm{O}$ profiles in ice cores from some smaller areas of MLSI provide a record of environmental conditions during the first year of ice growth, such as local hydrography and contribution of congealed snow to the solid fast ice. On ice charts we found no record of waxing and waning MLSI in the area, and do not know whether the observed ice survived the next summer. Since arctic ice shelves have developed from MLSI in the past, the observed phenomenon permits a view of how transitions from interglacial to full glacial conditions can begin.
\end{abstract}

Key words: multiyear land-fast sea ice, incipient ice shelves, sediment entrainment, interglacial/glacial transition, Siberia, Laptev Sea

RÉSUMÉ. Une zone de banquise côtière large de $20 \mathrm{~km}$, atteignant au large l'isobathe de $20 \mathrm{~m}$ et obturant les anses de la côte le long de la presqu'île de Taïmyr, est restée en existence au moins jusqu' au 23 novembre 1993, devenant ainsi une banquise côtière pluriannuelle. Le cordon d'îles montre des flèches recourbées caractéristiques indiquant une direction dominante sud-est pour la dérive littorale au cours des années intermittentes. Au moment de l'observation, la banquise côtière n'était pas perturbée, témoignant seulement d'un pilonnement vertical dû aux marées, et protégeait le littoral du remaniement par les vagues. La couverture de glace de 1 à $2 \mathrm{~m}$ d'épaisseur affecte la lumière et l'oxygène, et a des répercussions importantes sur la vie marine dans cette zone. Un troupeau de morses, qu'on avait vus les autres étés terrir sur les plages locales, a été délogé par la banquise. On n'a pas trouvé de preuve d'une charge solide de la glace par les rivières ou d'une sédimentation éolienne sur la glace.

La banquise côtière pluriannuelle est vue comme l'amorce d'une plate-forme glaciaire, qui pourrait croître en épaisseur et en résistance au cours des hivers subséquents. Les profils de salinité et de $\delta^{18} \mathrm{O}$ dans les carottes de glace provenant de quelques zones plus petites de banquise côtière pluriannuelle fournissent un relevé des conditions environnementales au cours de la première année de croissance de la glace, telles que l'hydrographie locale et l'apport de neige congelée à la banquise solidifiée. Sur les cartes des glaces, on ne trouve aucune donnée de l'avancée et du recul de la banquise côtière pluriannuelle dans la région, et on ne peut savoir si la glace observée était toujours présente l'été suivant. Vu que, dans le passé, les plates-formes de glace arctique se sont formées à partir de glace pluriannuelle, le phénomène observé permet de voir comment peut débuter la transition des conditions de phase interglaciaire aux conditions de phase glaciaire proprement dite.

Mots clés: banquise côtière pluriannuelle, amorce de plates-formes glaciaires, entraînement des sédiments, transition de la phase interglaciaire à la phase glaciaire, Sibérie, mer des Laptev

Traduit pour la revue Arctic par Nésida Loyer.

\section{INTRODUCTION}

During cruise ARK IX-4 in August and September 1993, the German research vessel Polarstern conducted multidisciplinary studies in the Laptev Sea, Siberia (Fig. 1). Beginning on August 8, when the ship had approached the Laptev Sea close enough to receive remote-sensing data from the area with its Advanced Very High Resolution Radiometer (AVHRR) satellite receiving station, a crescent- shaped ice region began showing along the eastern side of the Taymyr Peninsula. This fast ice, also observed on a helicopter reconnaissance flight, survived the summer melt season (Fig. 2), when it became multiyear land-fast sea ice. Following the usage of Jeffries et al. (1989), we refer to this ice as MLSI. This study describes the above MLSI, and presents data on the structure, salinity and $\delta^{18} \mathrm{O}$ of similar but less extensive ice off the Severnaya Zemlya Islands to the north.

\footnotetext{
${ }^{1}$ U.S. Geological Survey, 345 Middlefield Rd., MS 999, Menlo Park, California 94025, U.S.A.

${ }^{2}$ Alfred-Wegener-Institut für Polar und Meeresforschung, Postfach 120161, Columbusstr., D-27515 Bremerhaven, Germany

(C) The Arctic Institute of North America
} 


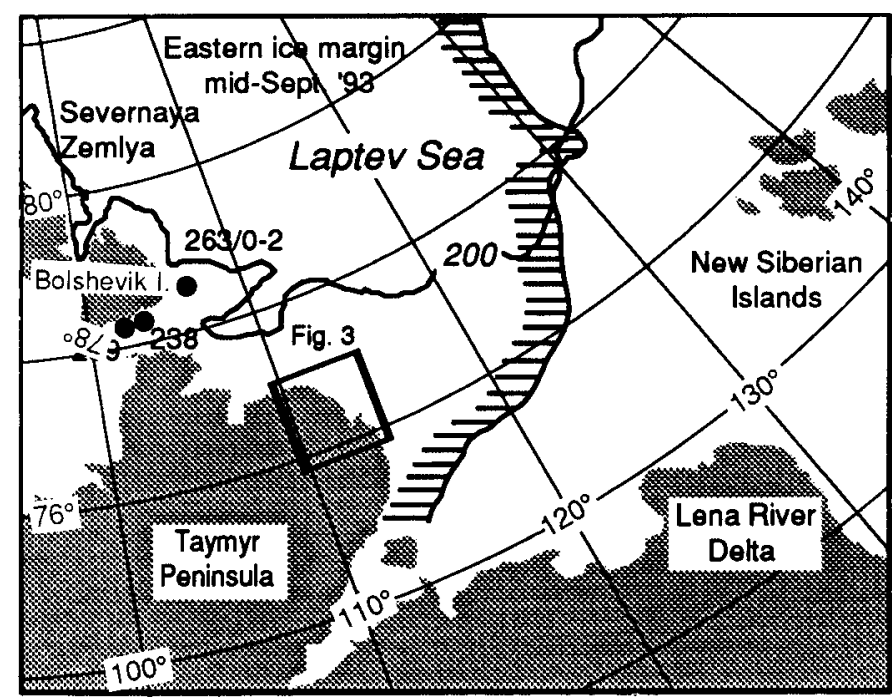

FIG. 1. Map showing the Laptev Sea and boxed area of MLSI depicted in Figure 3. Numbered dots are MLSI coring sites, isobaths are in meters, and the ice margin delineates open water to the east.

\section{BACKGROUND INFORMATION}

Western scientists have only sketchy knowledge of the wide, shallow Laptev Sea and its ice regime. Brigham (1991) provided some general information gathered mainly from interpretations of satellite images. On the basis of that report, we believe that the fast ice under study here (Fig. 2) may have been protected from wave erosion by a common summer intrusion of presumably older ice from the north along the Taymyr Peninsula, even though the east side of the Laptev Sea becomes rather ice-free. Russians refer to this recurring phenomenon as the Taymyr Ice Massif (Brigham, 1991). An expedition in April 1992 provided our first glimpse of the Laptev Sea with its $1800 \mathrm{~km}$ long, sinuous, perennial polynya curving southward to within $20 \mathrm{~km}$ of the Lena delta (Dethleff et al., 1993). The ice regime differs considerably from that anticipated by many researchers from years of shallow continental shelf studies in the North American Arctic, and other important differences extend over various facets of the marine environment (Reimnitz et al., 1994).

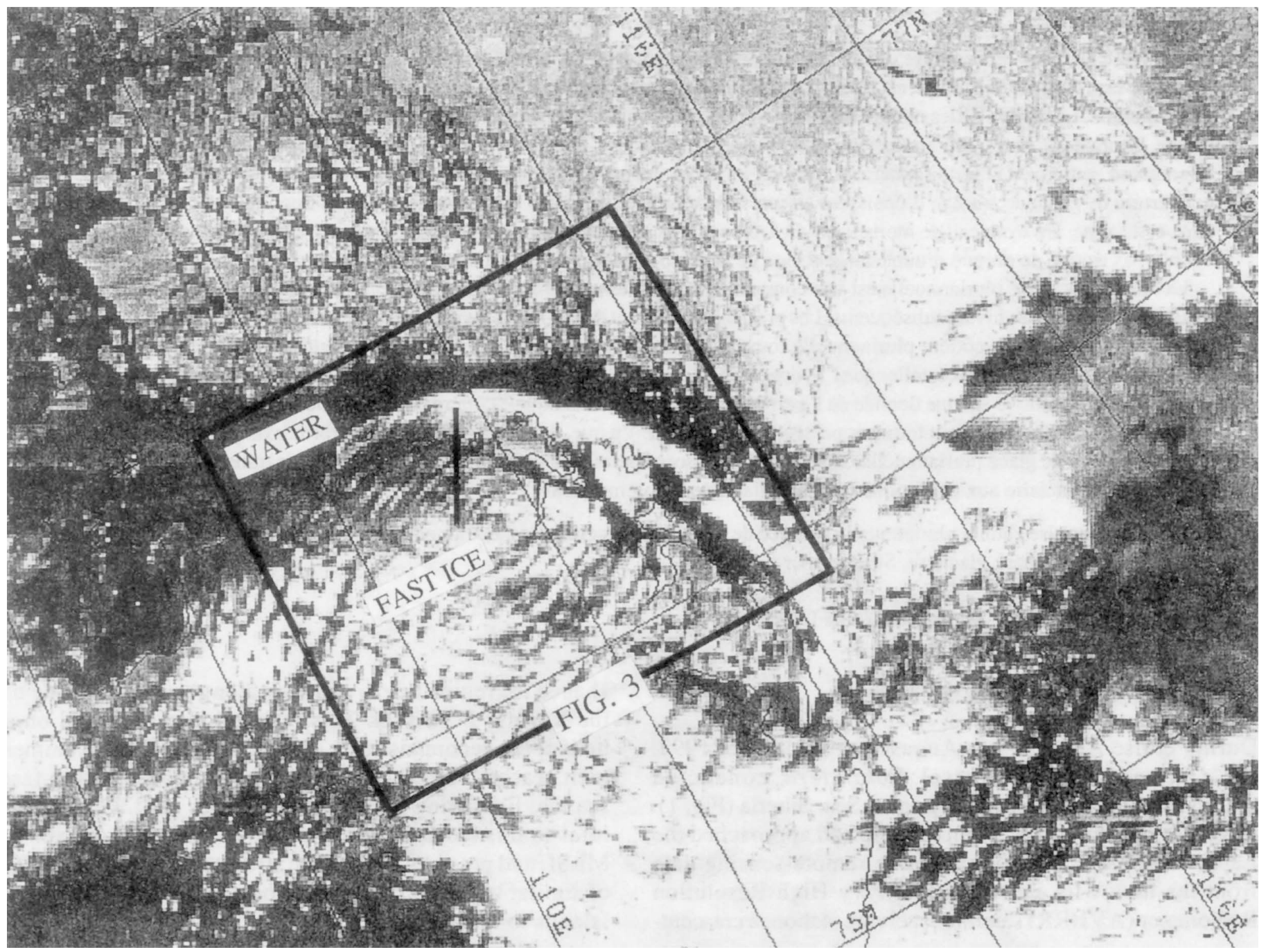

FIG. 2. AVHRR image (channel 1, 0.58-0.68 $\mu \mathrm{m}$ ) of the fast ice still remaining on 23 September 1993, after the onset of winter with new ice forming. Box delineates area mapped in Figure 3. 
As a background for understanding why the fast ice observed off Siberia is remarkable for scientists with field experience in the North American Arctic, we briefly describe such ice and its summer fate off northern Alaska. The Alaskan fast ice generally extends from the mainland shore seaward to the $20 \mathrm{~m}$ isobath, where its edge is stabilized by massive grounded pressure ridges. Chains of barrier islands become engulfed by the fast ice. By winter's end it reaches a thickness of 1.8 to $2.0 \mathrm{~m}$, and covers a zone averaging $15 \mathrm{~km}$ wide (Reimnitz et al., 1978). Most of the fast ice is freely floating, but there are $10 \mathrm{~km}$ wide regions shallower than $2 \mathrm{~m}$, in which the ice actually becomes "bottom fast." This bottom-fast ice is separated from the floating fast ice by tidal cracks. Many years of monitoring Landsat images, as well as personal small-boat observations, have shown that the bottom-fast ice melts first off northern Alaska. In the Prudhoe Bay region, where the zone is enclosed by offshore islands, it becomes a $160 \mathrm{~km}$ long shore lead reaching from the Colville to the Canning River two to three weeks before the area seaward is passable by small boats.

The Taymyr belt of fast ice described here actually survived the summer melt season in 1993, and at that point became multiyear ice (World Meteorological Organization, 1970), here referred to as MLSI . Little is known about the genesis and behavior of MLSI, which should be very sensitive to global environmental change and may have been instrumental in the formation of ice shelves during the last ice age. The following presents observations of such ice off Siberia, where, according to some workers (e.g., Grosswald, 1990), massive ice may have been widespread during the Pleistocene.

\section{METHODS OF STUDY}

AVHRR satellite data provide images with a ground resolution of $1.1 \mathrm{~km}$ in the nadir. All images were rectified and coastlines superimposed. Eight useful satellite scenes with relatively little cloud cover in the study area were recorded during the entire period of the Polarstern cruise. On such images the crescent-shaped area of initially suspected fast ice occasionally was well-defined, allowing changes to be monitored until September 23, well after new ice growth had begun (Fig. 2). While no decrease in ice area could be detected for the crescent-shaped feature, fast ice originally covering the embayments just to the west (Fig. 2) was completely removed during the period between August 8 and September 23. In synthetic aperture radar satellite data (not shown here), fast ice later cored off the small Starokadomskiy Island at 263/0-2 in Figure 1 was monitored until late November 1993, and therefore certainly also survived the winter.

On August 30, when the Polarstern passed within helicopter range of the eastern side of Taymyr Peninsula, a GPScontrolled flight was made to the area of suspected fast ice and confirmed it as such. The aerial observations made during this flight were combined with an interpretation of ice types and open water areas on a good AVHRR image of August 31, and plotted on the Russian navigational chart \#949 at a scale of 1:700 000. The coastline and the $10 \mathrm{~m}$ and $20 \mathrm{~m}$ isobaths from that chart are shown together with our flight line and the ice information in Figure 3. On September 1, a Russian plane equipped with X-band radar also imaged the fringe of fast ice.

The ship's schedule did not permit sampling the MLSI off the Taymyr Peninsula. However, cores taken on August 28 and September 20 from similar, but less extensive ice off Severnaya Zemlya to the north (Fig. 1) allow some speculation about the structure and physical properties of the MLSI delineated in Figures 2 and 3.

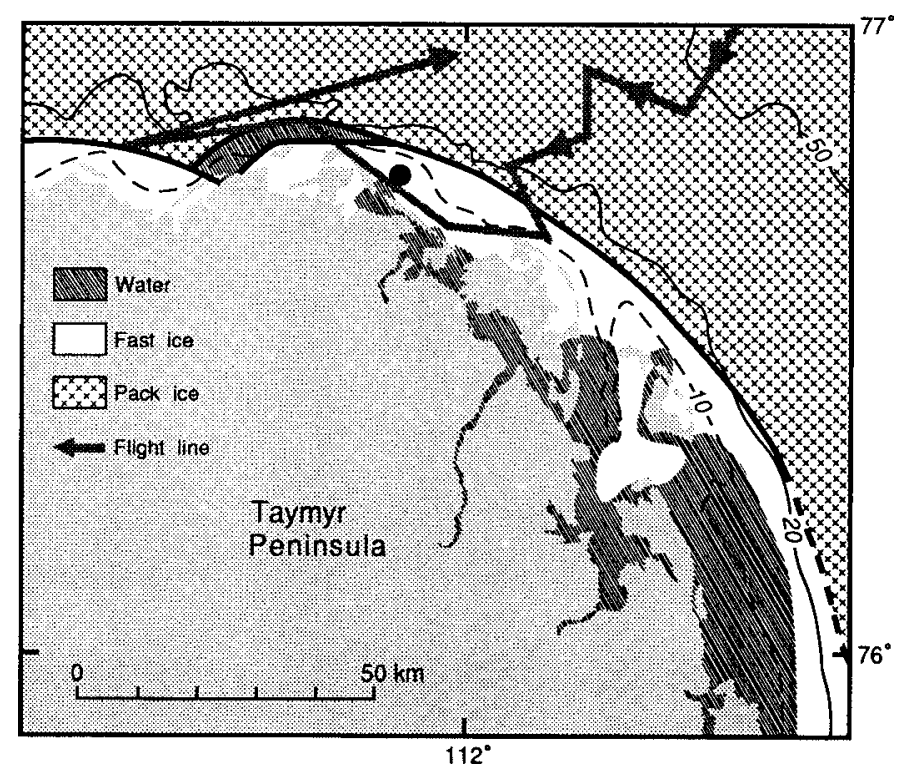

FIG. 3. Map showing the extent of fast ice and of open water drawn from a combination of aerial observations on August 30, and an AVHRR image on 31 August 1993. The coast and 10 and $20 \mathrm{~m}$ depth contours are from a Russian sailing chart. Our flight line is shown, with a black dot marking the location from which Figure 4 was photographed.

\section{RESULTS}

AVHRR images, Russian radar flights, and shipboard observations showed high concentrations of thick sea ice in the western half of the Laptev Sea, with open water dominating the eastern half, as shown in Figure 1. Thus the Taymyr Ice Massif mentioned before seemed well developed during the summer.

Our aerial reconnaissance flight to the Taymyr Peninsula revealed that the crescent-shaped area of suspected fast ice seen in satellite images was indeed an unbroken expanse of ice extending to the coast over long distances. An irregular belt of open water several meters to tens of meters wide had formed locally along the shoreline, but elsewhere small pressure ridges, or pile-ups, rimmed the beaches. In Figure 4 such linear pile-ups exist on both sides of a barrier spit, whose surface pattern of recurved spits indicates wave-construction and littoral transport toward the east and south. The fast ice generally had a smooth surface. A lack of ridged ice along the boundary between the crescent-shaped fast ice and drifting 
pack ice, also noted on the radar image, is noteworthy. The closed ice pack without open-water patches shown seaward of the fast ice in images of early August suggests some landward pressure at that time, but evidently it was not strong enough to develop pressure ridges within the fast ice.

Lagoons fed by local rivers were marked by open water (Fig. 3) with as much as $10 \mathrm{~km}$ of fetch. In a number of places, small tongues of open water with crenulated seaward boundaries extended from lagoons into the fast ice (Figs. 3 and 4), marking tidal inlets with net seaward flow of warm water below the ice. Barrier islands and spits, including re-curved spits (Fig. 4), indicate surf action which effectively shapes the coast in intermittent years. The last coastal process active in the area observed during the August 30 flight was shoreward ice pressure, which was producing small, linear ice pile-ups. The blocky surface roughness of the pile-ups suggested they had not been smoothed by alternating summer melt and winter snow-drifts, but formed during the previous fall. The fast ice, therefore, had protected the coastal zone and estuaries from all but tidal action during the summer. No signs were seen of eolian transport of sediment from land onto the sea ice with prevailing offshore winds during the previous winter (Gorshkov, 1980).

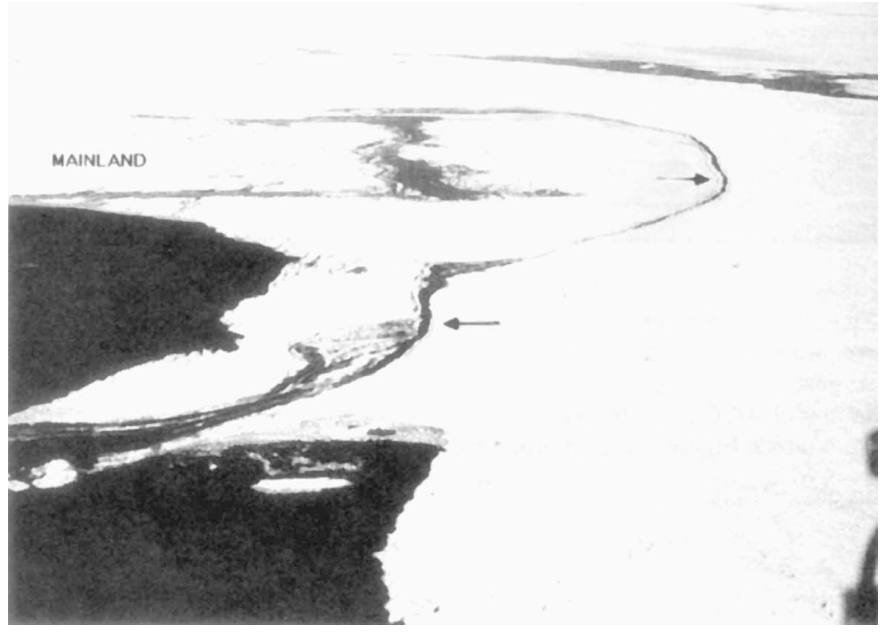

FIG. 4. Oblique aerial photograph looking westward (see location in Fig. 3) of a barrier island surrounded by fast ice on August 30. A series of re-curved spits indicates wave action in some summers. Small pressure ridges along both sides of the island (indicated by arrows) probably formed during the previous fall. Small-scale crenulations in the fast-ice/lagoon boundary are likely related to ice-thickness variations. Notice the lack of eolian dusting of the ice adjacent to the mainland shore in the background, which is dominated by offshore winter winds.

We studied four cores from two sites of unquestionable fast ice directly on (239) and near Bolshevik Island (263/0-2), and one from probable fast ice (238) (Fig. 1), which at the time, however, was detached from Bolshevik Island.

Core 239 was drilled in a $10 \mathrm{~m}$ wide ice fringe firmly attached to a rocky shore. The landward two thirds of this fringe was bottom-fast, while the outer third was rigidly suspended about $20 \mathrm{~cm}$ above the sea surface. Tidal information is not available. Coring showed the ice fringe was about $1 \mathrm{~m}$ thick. The upper $0.43 \mathrm{~m}$ of the core consisted of highly porous, orbicular, granular ice (Fig. 5A). The $\delta^{18} \mathrm{O}$ values of this upper layer ranged between $-22.2 \% o$ and $-20.7 \%$, and its salinity was $<0.1 \%$. Precipitation in the Severnaya Zemlya area typically exhibits $\delta^{18} \mathrm{O}$ between $-18 \%$ and $-22 \%$ o (Kotlyakov et al., 1990), since condensation along the travel path of air masses originating from the Atlantic or Pacific realm has resulted in a decrease of ${ }^{18} \mathrm{O}$ as compared to ${ }^{16} \mathrm{O}$. The low $\delta^{18} \mathrm{O}$ values are clear indications that the upper half of the fast-ice cover at the site had formed through congelation of snow blown onto an existing platform or into open water. The latter hypothesis is supported by the presence of a granular ice stratum at 0.43 to $0.57 \mathrm{~m}$ with intermediate $\delta^{18} \mathrm{O}$. A snow origin is also suggested by $80 \mathrm{~cm}$ high, longshore undulations in surface elevation of the ice fringe, interpreted as remnant sastrugi or snow drifts formed in that area by offshore winds. Lastly, the granular ice portion was speckled throughout with a few small sedimentary particles, suggesting that the snow with small amounts of sediment had been blown from land onto the ice. The lower half of the core consisted of layers of columnar and granular ice resulting from ordinary freezing of seawater. This origin was also indicated by the isotopic composition; the $\delta^{18} \mathrm{O}$ values of the parent water mass ranged between -1 and -2 , accounting for fractionation during freezing by $2.5 \%$. These values are fairly high in comparison with typical Laptev seawater, which ranges from $-20 \%$ at the mouth of the Lena River to $-1 \%$ at $79^{\circ} \mathrm{N}$ (Bauch, 1994). Thus, the western half of Vilkitskii Strait appears to be influenced mostly by water originating from the Kara and Barents Seas, the latter having $\delta^{18} \mathrm{O}$ values of around $0 \%$ (Bauch, 1994). The overall low salinities (see Fig. 5A) are noteworthy; they are the lowest measured in all core samples from the Laptev Sea. The dominant drainage mechanisms, i.e., meltwater flushing and gravity drainage (Weeks and Ackley, 1986), are driven by the hydrostatic head of the fresh water produced from melting of the snow layer at the top and by the density difference between the liquid phase within the brine pockets and the surrounding medium. Both of these processes were significantly enhanced at this particular site, since the fast-ice rim was suspended well above sea level. More important, however, is the effect of the snow-ice, which in part explains low salinities to roughly $0.5 \mathrm{~m}$ depth.

Cores 263/0, -1 , and -2 were obtained from a fast-ice belt along the coast of Starokadomskiy Island, a small island located a few miles off the southern tip of Bolshevik Island, as indicated in Figure 1.

Core 263/0 (Fig. 5B) was taken about $10 \mathrm{~m}$ seaward of a tidal crack separating bottom-fast ice from floating fast ice northeastward of the island, where the water depth was $6 \mathrm{~m}$. At the site the surface was slightly rough, with rhythmic surface undulations of few meters wavelength and 0.1 to 0.2 $\mathrm{m}$ amplitude. Drilled at a level spot, the ice was $1.4 \mathrm{~m}$ thick, consisting entirely of congelation ice grown in quiet water. Some of the ice $(0.17-0.57 \mathrm{~m})$ was highly porous and had undergone vigorous retexturing. The salinity profile is similar in shape to profiles of other cores, showing a steady increase from the top to approximately $1 \mathrm{~m}$ depth, but a rather low average value (Fig. 5B). The $\delta^{18} \mathrm{O}$ profile of this core 

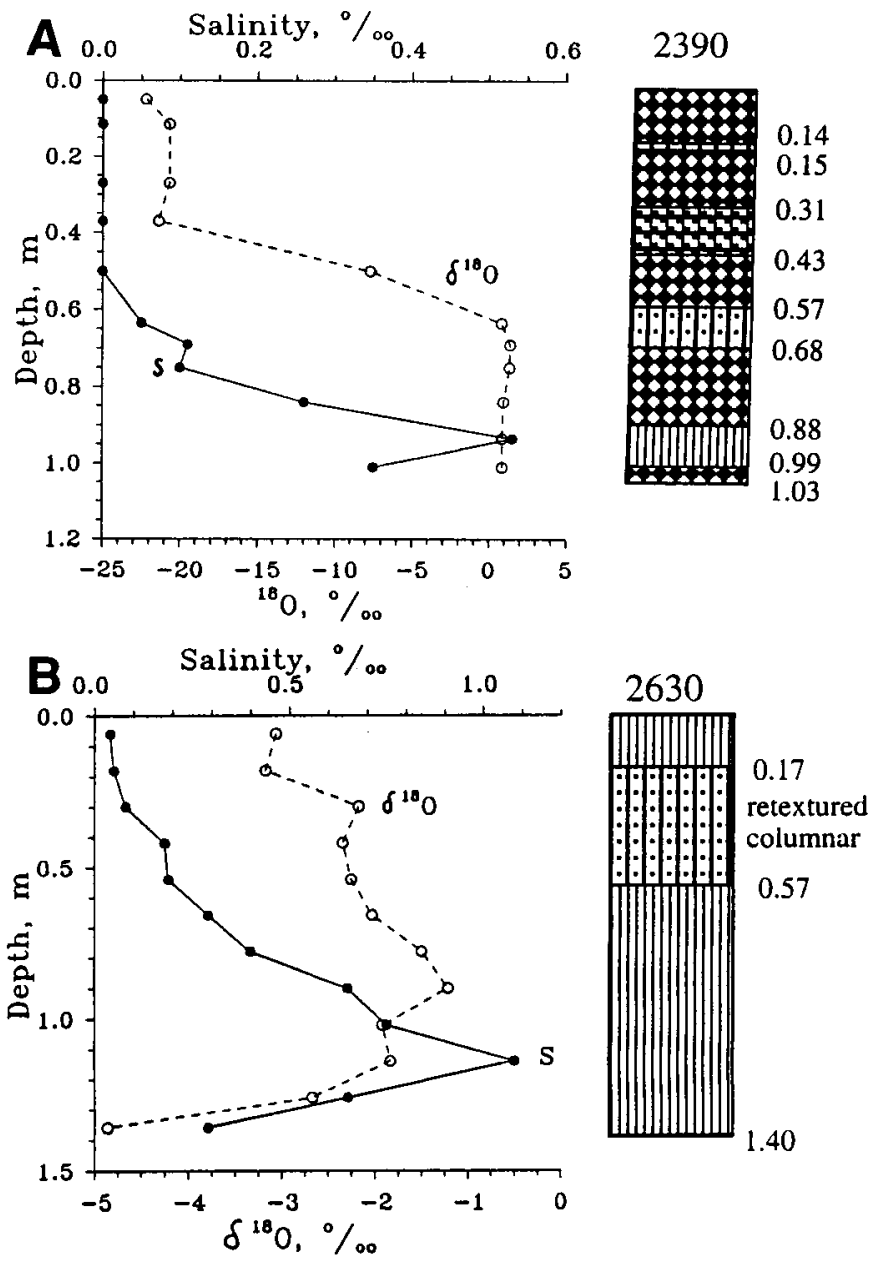

indicates that the composition of the water from which the ice grew remained comparatively stable throughout autumn and winter. Accounting for $2.5 \%$ o fractionation, the composition of the parent water mass would have ranged between $-3.5 \%$ o and $-7.0 \%$, which is typical for the Laptev Sea (Bauch, 1994). Nevertheless, the lower $\delta^{18} \mathrm{O}$ and the stronger fluctuations suggest a more prominent influence of fresh water, as from surface runoff or snow melt, when compared to core 239 in western Vilkitskii Strait. The strong decrease towards the bottom, with a parallel trend in salinity, may be due to an infiltration of low-salinity meltwater from below, as observed under arctic multiyear pack ice during summer (Eicken, 1994). This trend, however, could also have been caused by a change in parent water composition during the last few weeks of the ice-growth season, possibly from advection of an isotopically light water parcel affected by a riverine or precipitation signal. Core 263/1 (not shown) was taken $500 \mathrm{~m}$ farther seaward in completely level ice extending out from the rougher nearshore ice. The $1.27 \mathrm{~m}$ long core also consisted exclusively of congelation ice that was highly retextured, with numerous brine channels in the retextured layers. The bottom $0.1 \mathrm{~m}$ consisted of fine-grained, layered columnar ice. Salinities were similar to those of core 263/0 above.

Core 263/2 (Fig. 5C) is from the opposite side of the $40 \mathrm{~m}$ wide, $1.5 \mathrm{~m}$ high barrier island, $50 \mathrm{~m}$ into a shallow lagoon, where the water depth was $5.3 \mathrm{~m}$. The coring site was separated from the barrier island by a $15 \mathrm{~m}$ wide, $<1 \mathrm{~m}$ deep shore lead, which at the time already was covered by $15 \mathrm{~cm}$ of new ice. The ice surface here was even rougher than at site 263/0. The ice was $1.76 \mathrm{~m}$ thick, composed entirely of congelation ice with coarse-grained crystals. The average core salinity was much higher than that of other fast-ice samples, although the standard profile-with a linear increase to approximately $1 \mathrm{~m}$ depth and near-constant values below-is again displayed (Fig. 5C). The $\delta^{18} \mathrm{O}$ was in the same range as that of core $263 / 0$ and others from the area. The strong discontinuity at $0.85 \mathrm{~m}$ depth with near-constant values below suggests that the lagoon is in hydraulic communication with the open sea (Fig. 5C).

While the distribution of crystal orientation with depth has not been studied here, Strakhov (1991) found c-axes to be aligned NW-SE, or parallel to the coastline, in the fast ice along the eastern margin of the Severnaya Zemlya Islands. He attributed this to a persistent alongshore current.

\section{DISCUSSION}

There are only a few areas where MLSI is known to occur around the Arctic Ocean. Along the northern and eastern coast of Greenland, MLSI is commonly found, but it is nowhere as extensive as that mapped along the Taymyr Peninsula in 1993. Wadhams (1981) has given the most recent account of such ice, called "sikussak" when it becomes over ten years old. We studied small-scale, monthly ice charts published by the Naval Polar Oceanography Center, which reached back to the year 1981, but did not include 1993.

FIG. 5. Textural stratigraphies, salinities (solid lines), and $\delta^{18} \mathrm{O}$ (dashed lines) the text). A: Core 239 off Bolshevik Island. Low overall salinities are a result of enhanced brine drainage and meltwater flushing. The upper $0.43 \mathrm{~m}$ are composed mostly of congealed snow. B: Core 263/0 from seaward of Starokadomskiy Island. C: Core 263/2 from a shallow lagoon at Starokadomskiy Island. 
According to these ice charts, some fast-ice remnants survived off northern and eastern Greenland during all summers except that of 1991.

MLSI is widespread along the northern coast of Ellesmere Island, northern Canada (Jeffries et al., 1989; Jeffries, 1991, 1992). This ice is as much as $10 \mathrm{~m}$ thick, and at least 20 years old. It is locally underlain by brackish water during the summers, and includes significant volumes of brackish ice. The surface of the MLSI at Ellesmere Island is marked by linear undulations with a wavelength of about $60 \mathrm{~m}$ (Jeffries and Serson, 1986). Important for speculations about changes in climate and ice regimes in the Arctic is the fact that the massive ice shelves of Ellesmere Island grew in part from sea ice surviving through several summers (Jeffries et al., 1989; Jeffries, 1991, 1992).

We have no reliable information about the recurrence interval for the development of MLSI along the Taymyr Peninsula. Judging by the fresh appearance of ice pile-ups on the shore, open water existed in the region of remaining fast ice during the previous freeze-up. The same Naval Polar Oceanography Center ice charts that show fast-ice remnants along northern Greenland in most years since 1981 do not show such ice in the present study area. Moreover, largerscale weekly ice charts, kindly provided by David Benner of the Polar Oceanography Center (pers. comm., 1994), for the months of our expedition, do not show the fast ice persisting through that period. Finally, unpublished Russian ice charts show fast ice in our Taymyr study area during early August 1993, but suggest its disappearance during the course of August, when we observed it. Ice charts, therefore, are not sufficiently detailed to monitor Siberian fast-ice remnants.

Fast ice remaining in place through the summer melt season in the coastal zone, which probably features open water in most years, has profound effects on all facets of the marine environment. The $>1 \mathrm{~m}$ thick ice inhibits access to the zone by small coastal vessels, and it restricts the movement of certain sea mammals, such as walrus, which according to a Russian atlas inhabit this area (State Committee of the USSR for Hydrometeorology and Control of the Natural Environment, 1985). More specifically, the mainland shore of Pronchishchev Bay, where in normal summers a walrus herd of several hundred reportedly hauls out onto land (Shereshevskii, 1960), was made inaccessible to the animals by extensive fast ice in 1993. A vast sheet of ice also reduces light levels during the summer growth season, especially if the ice contains any sediment (Dunton, 1990; Dunton et al., 1992), and hence greatly reduces primary production on the shallow shelf. The ice canopy eliminates wave and ice reworking of bottom sediments, protects the coast from erosion, and effectively inhibits sediment entrainment by suspension freezing during low-temperature storms (Reimnitz et al., 1992, 1993).

The outer edge of the fast ice remaining through the summer of 1993 roughly corresponded to the outer edge of fast ice mapped and also recorded repeatedly on AVHRR images by the Russians during the entire winter of 1991/92 (Dethleff et al., 1993). This boundary therefore approximates the location of the perennial winter flaw-lead, which is formed and maintained under prevailing offshore winds. Lack of pressure ridges, particularly along the seaward edge of the fast ice seen by us and in side-looking airborne radar data collected during the cruise, indicates that the preceding year provided no major onshore pressure events in this area. The floating fast ice heaved only vertically with the tides and apparently experienced little or no lateral movement during the previous year.

Lagoons in arctic Alaska at the end of the ice growth period have sub-ice salinities between $48 \%$ and $56 \%$ o due to brine rejection (Schell, 1974; Mathews and Stringer, 1984). In an Alaskan tidal inlet between barrier islands, discharge flushed this brine within several hours after river break-up, replacing it with fresh water (Mathews and Stringer, 1984). We assume that conditions are similar in the lagoons below the fast ice of the Taymyr Peninsula. We also assume that river water, as off northern Alaska, originally flooded some of the fast ice. As in offshore Alaska, however, we saw no fluvial deposits on fast ice by the end of August. The high salinity measured in the core from the fast-ice remnant within a lagoon near Bolshevik Island (core 263/2) (Fig. 5C) could be explained by enhanced salt concentration within the confined lagoon. However, sea-ice salinities are known to be quite variable, depending in particular on the amount of meltwater flushing during the summer (Weeks and Ackley, 1986); hence, the observed differences may be a result of variability due to other processes.

Very little snow had accumulated on land and ice by August 30 (Fig. 4). The fact that the MLSI showed no surficial eolian dust where exposed to prevailing offshore winds from the Siberian mainland attests to the relative unimportance of this entrainment mechanism. The relative insignificance of wind transport for loading sea ice with continental sediments is supported by the sparsity of lithic clasts in the congealed snow cored on the fast ice at site 239. Our flying altitude of $1250 \mathrm{~m}$ was too high for reliable observation in the fast ice of patchy sediment inclusions from mechanisms other than eolian dusting. From the ship, however, we could observe very heavy and patchy sediment loads in individual pack-ice floes seaward of the MLSI.

New ice was already forming by the time of the last AVHRR image that showed the MLSI remaining intact (Fig. 2). Offshore ice advection by wind in late fall could still have produced sufficient fetch that year to generate large storm waves in the Laptev Sea. Exposed to a wave train, a sheet of ice systematically fractures at a distance from the edge that is dependent mainly on ice thickness (Squire, 1993). For the range of MLSI thicknesses measured to the north of our observation site, the cracks would be expected to form about 50 to $100 \mathrm{~m}$ from the edge (Squire, 1993), freeing roughly equi-size slabs for removal by drifting. Such action could still have destroyed the MLSI in 1993. Because of the southward extent of the Taymyr Ice Massif, however, reaching hundreds of kilometers southward beyond the fast ice during the fall of 1993, this seems unlikely to us. We are not aware of any unusual meteorological conditions in 1993 to 
which we can attribute the survival of first-year ice through the entire melt season in the Taymyr coastal zone.

The MLSI is likely to thicken further and become firmer during the second winter through the addition of snow and basal freezing (Maykut and Untersteiner, 1971). During summer 1994, for example, more heat or runoff would have been required to remove this aging MLSI than were available during the first melt season. Snow addition may be especially important for the coast of the Severnaya Zemlya archipelago, where significant amounts of drifting snow accumulate. Here a large fraction of the fast-ice thickness could simply form from the congelation of this snow. Once it exceeded a threshold annual accumulation value of about $0.75 \mathrm{~m}$, the snow cover could be instrumental in the build-up of a thick ice cover because of its surface "shielding effect" (Maykut and Untersteiner, 1971).

Jeffries (1992:250) wrote, "MLSI can be regarded as incipient ice shelf and may provide a key toward further understanding the development of sea-ice ice shelves." Because of the fixed location of such ice, and its slow downward growth into quiet water below, its isotopic composition and other properties will record the history of local environmental conditions, as shown above. This is of particular interest in locations such as Vilkitskii Strait, the important passageway for water exchange between the Kara and Laptev Seas.

Remote sensing tools presently used for preparing ice charts evidently lack sufficient resolution to delineate such "incipient ice shelves" in the arctic coastal zone. We therefore suspect that previous MLSI belts may have gone undetected in the study area during the past decade, and that similar features exist intermittently elsewhere in the vast, remote Siberian coastal zone.

The ice covers of lagoons, such as the one at Starokadomskiy Island, are of particular importance as potential ice-shelf nuclei. First, ice growth is enhanced in such areas through greatly reduced oceanic heat flux, as demonstrated by the differences in ice thickness between sites 263/0 and /1 and $263 / 2$. Second, MLSI in lagoons is largely protected from ocean swell and wave action and hence can be destroyed only by melting. Once the ice becomes grounded, further thickening depends on the balance between surface melt and snow accumulation. Heat fluxes resulting from solar heating of the lagoon floor underneath an ice cover exceeding $2 \mathrm{~m}$ in thickness are not deemed sufficient to prevent fast-ice buildup, since radiation transfer modeling for the Arctic indicates that maximum summer heat fluxes sustained in this manner are from $<1$ to $5 \mathrm{~W} \mathrm{~m}^{-2}$ (Jin, 1994). Provided that oceanic heat flux is small or entirely negligible, which holds for many coastal sites, model results suggest that a multiyear ice cover can attain thicknesses of more than 10 meters within a few decades (Maykut and Untersteiner, 1971; Walker and Wadhams, 1979). An assessment of the evolution of MLSI thickness, however, greatly depends on summer surface ablation, and this is much more difficult to estimate and may vary considerably between different locations and years.

Intermittent development and decay of MLSI in arctic regions demonstrate that only subtle climatic changes are required to cause local ice shelves to start forming during the present interglacial period. Many marine geologists working on problems of arctic paleoclimates and environmental changes probably have pondered the transition from an interglacial setting to a full glaciation; however, speculations about this transition, as far as we know, have not been published. If such a transition were in progress, the most noticeable changes would probably occur in the coastal regions, triggered by a reduction in river flow (as occurs now at the onset of winter), the preservation of fast ice, and the initiation of sea-ice ice shelves. We have speculated earlier about the drastic effects of lasting fast ice on the coastal environment, even before sea-level lowering begins. Widespread development and preservation of fast ice around the Arctic Ocean would greatly reduce sediment flux to the deep basins, as cross-shelf transport certainly was reduced in our restricted study area in 1993. Sediment flux to basins may increase later with continuing shoreline regression. This, however, would depend to a large extent on whether any seaice cover is preserved on the freshly exposed shelf surface as the shoreline recedes rapidly. Speculations beyond this point are not warranted.

\section{CONCLUSIONS}

Our summer 1993 studies in the Laptev Sea, focusing on the sea-ice regime of this poorly known region, allow the following conclusions to be made:

1. A $20 \mathrm{~km}$ wide belt and other smaller remnants of fast ice in the Laptev Sea survived their first summer melt season, thereby becoming multiyear land-fast sea ice (MLSI).

2. MLSI on the shallow Siberian shelf arrests coastal processes, protects beaches, eliminates the normal entrainment processes, and thereby reduces shelf/basin sediment exchange.

3. MLSI reduces biological productivity below its cover, and prevents access for walrus and other sea mammals and also for small coastal vessels that normally enter embayments and rivers.

4. The physical and chemical properties of old fast ice record important information about environmental conditions during its growth and aging.

5. Aerial observations and a core of congealed snow accumulated under offshore winds show eolian deposition on Siberian ice is relatively insignificant.

6. MLSI is reported for only a few sites in North America. Neither U.S. nor Russian ice charts reveal the existence of MLSI in the present study area, and available remote sensing data therefore are inadequate to study its waxing and waning with short-term climatic variations. 
7. Arctic ice shelves, formerly more widespread, developed partly from fast ice. Fast ice proceeding through its second year in our study area provides a sense of how the Little Ice Age might have forced man living in the coastal zone to adapt to a rapidly changing habitat.

\section{ACKNOWLEDGEMENTS}

We thank the ship's officers and crew for the wonderful work environment they provided for us during the long cruise, and pilots Büchner and Brinkmann for their efficient and safe helicopter operations. We also thank D. Benner of the National Ice Center for his personal assessment of ice types mapped by the Center in 1993 in the study area, and B. Fay for sending us his own translations from Russian about walrus habits and habitats in the Laptev Sea. The help of N. Scheele and G. Traue in measuring $\delta^{18} \mathrm{O}$ is gratefully acknowledged, as are the critical reading and suggestions for improvements of our manuscript by M. Jeffries, D. Dinter, T. Kozo, and an anonymous reviewer. This is publication No. 842 of the Alfred Wegener Institute for Polar and Marine Research.

\section{REFERENCES}

BAUCH, D. 1994. The distribution of $\delta^{18} \mathrm{O}$ in the Arctic Ocean: Implications for the freshwater balance of the halocline and the sources of deep and bottom waters. Reports on Polar Research 159:1-144.

BRIGHAM, L.W. 1991. The Soviet maritime: Polar research series. London: Belhaven Press. 47-62.

DETHLEFF, D., NÜRNBERG, D., REIMNITZ, E., SAARSO, M., and SAVCHENKO, V.P. 1993. The Laptev Sea-Its significance for arctic sea-ice formation and transpolar sediment flux. Bremerhaven: Alfred-Wegener-Institut für Polar-und Meeresforschung, Report 120:3-44.

DUNTON, K.H. 1990. Growth and production in Laminaria solidungula: Relation to continuous underwater light levels in the Alaskan high Arctic. Marine Biology 106:297-304.

DUNTON, K.H., SCHONBERG, S.V., MARTIN, L.R., and MUELLER, G.S. 1992. Seasonal and annual variations in the underwater light environment of an arctic kelp community. In: Cahoon, L.B., ed. Diving for science: Twelfth Annual Scientific Diving Symposium. Costa Mesa, California: American Academy of Underwater Sciences. 83-92.

EICKEN, H. 1994. Structure of under-ice ponds in the central Arctic and their effect on the sea-ice cover. Limnology and Oceanography 93(3):682-694.

GORSHKOV, S.G. 1980. World Ocean Atlas: Arctic Ocean. New York: Pergamon Press. 3.

GROSSWALD, M.G. 1990. Late Pleistocene ice sheet in the Soviet Arctic. In: Kotlyakov, V.M., and Sokolov, V.E., eds. Arctic research, advances and prospects, Part 2. Proceedings of the Conference of Arctic and Nordic Countries on Coordination of Research in the Arctic. Moscow: Nauka. 18-23.

JEFFRIES, M.O. 1991. Massive, ancient sea-ice strata and preserved physical-structural characteristics in the Ward Hunt ice shelf. Annals of Glaciology 15:125-131.
1992. Arctic ice shelves and ice islands: Origin, growth and disintegration, physical characteristics, structuralstratigraphic variability, and dynamics. Review of Geophysics 30(3):245-267.

JEFFRIES, M.O., and SERSON, H.V. 1986. Survey and mapping of recent ice shelf changes and landfast sea ice growth along the north coast of Ellesmere Island, NWT, Canada. Annals of Glaciology 8:96-99.

JEFFRIES, M.O., KROUSE, H.R., SACKINGER, W.M., and SERSON, H.V. 1989. Stable-isotope $\left({ }^{18} \mathrm{O} /{ }^{16} \mathrm{O}\right)$ tracing of fresh, brackish, and sea ice in multi-year land-fast sea ice, Ellesmere Island, Canada. Journal of Glaciology 35(19):9-16.

JIN, Z. 1994. The effect of sea ice on the solar energy budget in the atmosphere-sea ice ocean system: A model study. Journal of Geophysical Research 99:25281-25294.

KOTLYAKOV, V.M. 1990. Drilling on ice caps in the Soviet Arctic and on Svalbard and prospects of ice core treatment. In: Kotlyakov, V.M., and Sokolov, V.E., eds. Arctic research, advances and prospects, Part 2. Proceedings of the Conference of Arctic and Nordic Countries on Coordination of Research in the Arctic. Moscow: Nauka. 5-17.

MATHEWS, J.B., and STRINGER, W.J. 1984. Spring breakup and flushing of an arctic lagoon estuary. Journal of Geophysical Research 89(C2):2073-2079.

MAYKUT, G.A., and UNTERSTEINER, N. 1971. Some results from a time dependent thermodynamic model of sea ice. Journal of Geophysical Research 76:1550-1575.

REIMNITZ, E., DETHLEFF, D., and NÜRNBERG, D. 1994. Contrasts in arctic shelf sea-ice regimes and some implications: Beaufort Sea versus Laptev Sea. Marine Geology 119:215-225.

REIMNITZ, E., MARINCOVICH, L., McCORMICK, M., and BRIGGS, W.M. 1992. Suspension freezing of bottom sediment and biota in the Northwest Passage and implications for Arctic Ocean sedimentation. Canadian Journal of Earth Sciences 29:693-703.

REIMNITZ, E., McCORMICK, M., McDOUGALL, K., and BROUWERS, E. 1993. Sediment-export by ice rafting from a coastal polynya, Arctic Alaska. Arctic and Alpine Research 25(2):83-98.

REIMNITZ, E., TOIMIL, L., and BARNES, P. 1978. Arctic continental shelf morphology related to sea-ice zonation, Beaufort Sea, Alaska. Marine Geology 28:179-210.

SCHELL, D.M. 1974. Regeneration of nitrogenous nutrients in arctic Alaskan estuarine waters. In: Reed, J.C., and Sater, J.E., eds. The coast and shelf of the Beaufort Sea. Arlington, Virginia: Arctic Institute of North America. 649-664.

SHERESHEVSKII, E.I. 1960. The walrus (Odobaenus rosmarus L.), its distribution and migrations in the Laptev Sea. Migrations of Animals 2. Moscow: Academy of Science USSR. 27-37.

SQUIRE, V.A. 1993. The breakup of shore fast ice. Cold Regions and Science Technology 21:211-218.

STATE COMMITTEE OF THE USSR FOR HYDROMETEOROLOGY AND CONTROL OF THE NATURAL ENVIRONMENT. 1985. Atlas of the Arctic. Map \#40, Distribution of walrus and routes of contact between populations. Moscow: Main Administration of Geodesy and Cartography under the Soviet Ministries of the USSR. 
STRAKHOV, M.V. 1991. A study of the influence of currents on the formation of an ice cover with an aligned crystal structure in the polar seas. International Association of Hydrological Science. Publication No. 208:95-103.

WADHAMS, P. 1981. The ice cover in the Greenland and Norwegian Seas. Reviews of Geophysics and Space Physics 19(3):345393.

WALKER, E.R., and WADHAMS, P. 1979. Thick sea-ice floes. Arctic 32(2):140-147.
WEEKS, W.F., and ACKLEY, S.F. 1986. The growth, structure and properties of sea ice. In: Untersteiner, N., ed. Geophysics of sea ice. Dordrecht: Martinus Nijhoff Publishers. 9-164.

WORLD METEOROLOGICAL ORGANIZATION. 1970. WMO sea-ice nomenclature. Geneva: Secretariat of the World Meteorological Organization. 